\title{
Analisis Neraca Air Lahan untuk Tanaman Padi dan Jagung di Kota Bengkulu
}

\author{
Jaka Anugrah Ivanda Paski*, Gita Ivana S L Faski, M. Fajar Handoyo, Dyah Ajeng \\ Sekar Pertiwi
}

1Badan Meteorologi Klimatologi dan Geofisika; e-mail: jaka.paski@yahoo.com

\begin{abstract}
ABSTRAK
Ketersediaan air tanah yang sebagian besar berasal dari curah hujan merupakan faktor pembatas yang penting bagi peningkatan produksi suatu tanaman. Neraca air merupakan suatu metode yang dapat digunakan untuk melihat ketersediaan air tanah bagi tanaman pada waktu tertentu. Prosedur perhitungan neraca air dibuat berdasarkan sistem tata buku Thorntwaite dan Mather (1957) dengan satuan tinggi air (mm). Analisis ketersediaan air tanah secara grafik disajikan dalam periode bulanan, mulai Januari hingga Desember secara klimatologis. Data yang digunakan dalam analisis ini adalah data rata-rata jumlah curah hujan bulanan dan suhu rata-rata bulanan tahun 1985-2011 dari Stasiun Klimatologi Pulau Baai Bengkulu yang mewakili daerah penelitian yaitu wilayah Kota Bengkulu dan data tanah Kota Bengkulu. Wilayah Kota Bengkulu memiliki ketersediaan air yang sangat cukup dengan persentase air tersedia setiap bulannya $100 \%$, yang dibuktikan dari hasil perhitungan, oleh karena itu Kota Bengkulu memiliki nilai surplus sepanjang tahun. Pada kondisi jumlah curah hujan bulanan yang cukup tinggi berkisar $179-458 \mathrm{~mm}$, suhu yang relatif rendah berkisar $25,9-26,9^{\circ} \mathrm{C}$, dan lahan dengan nilai surplus yang tinggi seperti ini, di wilayah Kota Bengkulu baik untuk ditanami padi, sedangkan untuk penanaman jagung kurang baik.
\end{abstract}

Kata kunci: neraca air, curah hujan, kesesuaian lahan, suhu udara, klasifikasi oldeman

\begin{abstract}
The availability of groundwater most of which comes from rainfall is an important limiting factor for increasing the production of a plant. Water balance is a method that can be used to see the availability of ground water for plants at a certain time. The water balance calculation procedure is based on the Thorntwaite and Mather book keeping system (1957) with water unit (mm). Analysis of groundwater availability graphically is presented in monthly periods, from January to December climatologically. The data used in this analysis is the average data of the amount of monthly rainfall and the average monthly temperature of 1985-2011 from Bengkulu Island Climatology Station representing the research area of Bengkulu City and Bengkulu City land data. Bengkulu City has a very good water supply with percentage of water available every month $100 \%$, as evidenced from the calculation, therefore Bengkulu City has surplus value throughout years. While conditions of high monthly rainfall is quite high ranging from $179-458 \mathrm{~mm}$, Relatively low temperatures ranging from $25.9-26.9^{\circ} \mathrm{C}$, and land with a high surplus value like this, in the area of Bengkulu City is suitable for planting rice, whereas for the planting of maize is less suitable.
\end{abstract}

Keywords: water balance, rainfall, land suitability, air temperature, oldeman classification

Citation: Paski, J.A.I., Faski, G.I.S.L., Handoyo, M.F. dan Pertiwi, D.A.S. (2017). Analisis Neraca Air Lahan untuk Tanaman Padi dan Jagung di Kota Bengkulu. Jurnal Ilmu Lingkungan, 15(2), 83-89, doi:10.14710/jil.15.2.83-89

\section{Pendahuluan}

Dalam suatu lingkungan ekosistem, ketersedian air sangat berperan. Konsep siklus hidrologi lingkungan menyatakan bahwa jumlah air di suatu luasan tertentu di permukaan bumi dipengaruhi oleh besarnya air yang masuk/menyerap (input) dan keluar (output) pada jangka waktu tertentu. Neraca masukan dan keluaran air di suatu tempat dikenal sebagai neraca air (water balance). Karena air bersifat dinamis maka nilai neraca air selalu berubah dari waktu ke waktu sehingga di suatu tempat kemungkinan bisa terjadi kelebihan air (surplus) ataupun kekurangan (defisit). Apabila kelebihan dan kekurangan air ini dalam keadaan ekstrim tentu dapat menimbulkan bencana, seperti banjir ataupun kekeringan. Bencana tersebut dapat dicegah atau ditanggulangi bila dilakukan pengelolaan yang baik terhadap lahan dan lingkungannya. Selain itu neraca air juga dapat dimanfaatkan dalam bidang pertanian, pengetahuan tentang neraca air pada suatu daerah dapat meningkatkan produksi. Pada skala sinoptik, adanya badai tropis di dekat wilayah Indonesia juga 
akan berpengaruh terhadap hujan yang terjadi di Indonesia (Wirjohamidjojo, 1995).

Menurut Sosrodarsono dan Takeda (1978), ditinjau dari penggunaannya di bidang hidrologi, neraca air merupakan penjelasan tentang hubungan antara aliran ke dalam (in flow) dan aliran ke luar (out flow) disuatu periode tertentu dari proses sirkulasi air. Neraca air merupakan kebutuhan mutlak bagi tanaman. Hillel (1972) mendefinisikan neraca air sebagai perincian tentang semua masukan, keluaran, dan perubahan simpanan air yang terdapat pada suatu lahan untuk menetapkan jumlah air yang terkandung di dalam tanah yang menggambarkan perolehan air (surplus atau defisit) dari waktu ke waktu. Curah hujan bersama evapotranspirasi yang didukung oleh sifat fisik tanah akan dapat memberikan keterangan penting tentang jumlah air yang dapat diperoleh untuk menentukan periode surplus atau defisit air lahan, air yang tidak dapat tertampung dan waktu terjadinya yang keseluruhannya hanya dapat dianalisis melalui perhitungan neraca air (Nasir dan Effendi, 1999). Di bidang Agroklimatologi, Frere dan Popov (1979) seperti yang dikutip oleh Oldeman dan Frere (1982). Neraca air adalah selisih antara jumlah air yang diterima oleh tanaman dan kehilangan air dari tanaman beserta tanah melalui evapotranspirasi.

Neraca air lahan merupakan neraca air untuk penggunaan lahan pertanian secara umum. Neraca ini bermanfaat dalam mempertimbangkan kesesuaian lahan pertanian,mengatur jadwal tanam dan panen, dan mengatur pemberian air irigasi dalam jumlah dan waktu yang tepat. Penentuan waktu tanam berdasarkan perhitungan neraca air dimanfaatkan untuk mengetahui dampak perubahan iklim terhadap ketersediaan air pada suatu wilayah (Rafi dkk., 2005; Bari dkk. 2006; Kumanbala dkk., 2010). Tanaman padi dan jagung merupakan dua dari sekian jenis tanaman yang termasuk dalam tanaman pangan utama. Informasi yang disajikan secara cepat dan tepat diharapkan dapat mendukung program pemerintah daerah kota Bengkulu dalam rangka mempertahankan serta meningkatkan produksi pertanian di kota Bengkulu khususnya peningkatan produksi bahan pangan.

Perhitungan neraca air memungkinkan untuk mengevaluasi dinamika air tanah dan penggunaan air oleh tanaman secara kuantitatif (Lascano, 2000), dan menghitung ketersediaan air secara spasial pada suatu wilayah tertentu (Latha dkk, 2010). Neraca air sangat berhubungan dengan curah hujan, suhu permukaan dan evapotranspirasi. Dalam perhitungan neraca air lahan, curah hujan merupakan variabel yang selalu berubah (Chang, 1968). Suhu udara permukaan adalah suhu udara bebas pada ketinggian 1.25 sampai dengan 2.00 meter dari permukaan tanah (Soepangkat, 1992). Suhu mempengaruhi pertumbuhan dan produktivitas tanaman, bergantung pada jenisnya (tanaman musim panas atau musim dingin).
Dalam prakteknya, untuk penentuan kehilangan air secara terpisah melalui kedua proses tersebut sulit dilakukan atau ditentukan, sehingga pengukuran jumlah air yang hilang dihitung sebagai total air yang hilang melalui evaporasi dan transpirasi, yang disebut dengan evapotranspirasi. Evapotranspirasi yang terjadi pada laju potensial (ETP) meningkat sampai titik layu dan akan turun drastis setelah itu (Veihmeyer dan Hendrickson, 1955). Tetapi, laju evapotranspirasi akan mengikuti garis linier dengan naiknya tekanan air (Thornthwaite dan Mather, 1957). Sementara itu, para ahli lain memadukan pendapat antar keduanya, bahwa ETP terjadi pada laju potensial untuk beberapa saat, kemudian menurun dengan cepat secara eksponensial (Pierce, 1958).

Penelitian ini membahas tentang kondisi neraca air lahan di Kota Bengkulu dan kesesuaian lahan di kota Bengkulu untuk penanaman tanaman padi dan jagung. Air sebagai subjek utama memeliki peran yang sangat besar dalam pengendalian lingkungan.

Penelitian dilakukan dengan menganalisis ketersediaan air tanah secara grafik yang disajikan dalam periode bulanan, mulai Januari hingga Desember secara klimatologis. Data yang digunakan dalam analisis ini adalah data rata-rata curah hujan bulanan dan suhu rata-rata bulanan tahun 1985-2011 dari Stasiun Klimatologi Pulau Baai Bengkulu yang mewakili daerah penelitian dan data tanah wilayah Kota Bengkulu. Tujuan penelitian ini adalah untuk mengetahui kondisi neraca air lahan di Kota Bengkulu dan aplikasinya terhadap bidang pertanian terkhusus tanaman padi dan jagung.

\section{Metode Penelitian}

\subsection{Data dan lokasi}

Data yang digunakan untuk mengetahui kondisi neraca air di Kota Bengkulu adalah data rata-rata curah hujan bulanan dan suhu rata-rata bulanan dari tahun 1985-2011. Data diambil dari Stasiun Klimatologi Pulau Baai Kota Bengkulu untuk mewakili wilayah Kota Bengkulu.

Stasiun Klimatologi Klas I Pulau Baai Kota Bengkulu terletak di daerah pinggiran pantai dengan ketinggian $8,5 \mathrm{~m}$ di atas permukaan laut dengan koordinat 030 51' 56" LS dan 1020 18' 43" BT, di sebelah barat berbatasan langsung dengan Samudera Indonesia dan sebelah timur berbatasan dengan Pegunungan Bukit Barisan.

\subsection{Metode pengolahan}

Untuk mendapatkan nilai surplus dan defisit air lahan digunakan data rata-rata jumlah curah hujan bulanan dan suhu rata-rata bulanan menggunakan perhitungan metode Thornthwaite yang dijabarkan. Pendugaan ETP metode Thorntwaite ini hanya menggunakan data suhu rata-rata bulanan saja.

Untuk memperoleh ETP dengan metode ini bisa dilakukan dengan perhitungan menggunakan metode 
Paski, J.A.I., Faski, G.I.S.L., Handoyo, M.F. dan Pertiwi, D.A.S. (2017). Analisis Neraca Air Lahan untuk Tanaman Padi dan Jagung di Kota Bengkulu. Jurnal Ilmu Lingkungan, 15(2), 83-89, doi:10.14710/jil.15.2.83-89

Tornthwaite dan Mather (1957), Menggunakan rumus empiris:

1. Evapotranspirasi untuk suhu di bawah $26,5^{\circ} \mathrm{C}$ $\mathrm{ETP}=1,6(10 \mathrm{t} / \mathrm{I}) \mathrm{a}$

2. Kolom Evapotranspirasi untuk suhu di atas atau sama dengan $26,5^{\circ} \mathrm{C}$

$\operatorname{ETP}\left(t \geq 26,5^{\circ} \mathrm{C}\right)=-0,0433 \mathrm{t}^{2}+3,2244 \mathrm{t}-41.545$

Dimana:

$\mathrm{ETP}=$ evaporasi potensial bulan ( $\mathrm{cm} / \mathrm{bulan})$

$\mathrm{t}=$ suhu rata-rata bulanan $\left({ }^{\circ} \mathrm{C}\right)$

I = akumulasi indeks panas dalam setahun, diperoleh dengan rumus:

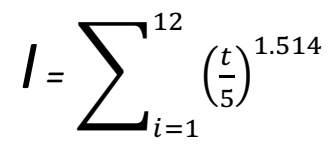

$\mathrm{a}=0,000000675 \mathrm{I}^{\mathrm{s}}-0,0000771 \mathrm{I}^{2}+0,01792$

$\mathrm{I}+0,49239$

Perhitungan neraca air lahan untuk melihat keseuaian tanaman padi dan jagung menggunakan beberapa parameter-parameter seperti APWL, KAT, dKAT, ETA dan ATS. Dengan rumus empiris seperti berikut:

a) Akumulasi potensial kehilangan air untuk penguapan (APWL)

b) Diisi dengan penjumlahan nilai CH-ETP yang negatif secara berurutan bulan demi bulan.

c) Kandungan air tanah (KAT)

$\mathrm{KAT}=\mathrm{TLP}+\left[[1,00041-(1,07381 / \mathrm{AT})]^{\wedge}|\mathrm{APWL}|\right.$ $\mathrm{x} \mathrm{AT}]$

d) Perubahan kadar air tanah (dKAT) dKAT $=$ KAT $($ bulan $\mathrm{x}$ ) - KAT (bulan $\mathrm{x}-1)$

e) Evapotranspirasi Aktual (ETA)

Bila $\mathrm{CH}>$ ETP maka ETA = ETP karena ETA mencapai maksimum.

Bila $\mathrm{CH}<$ ETP maka ETA $=\mathrm{CH}+|\mathrm{dKAT}|$.

f) Defisit

D = ETP - ET

g) Surplus

$$
\mathrm{S}=\mathrm{CH}-\mathrm{ETP}-\mathrm{dKAT}
$$

h) Air Tanah Tersedia (ATS)

$$
A T S=\frac{K A T-T L P}{K L-T L P} \times 100 \%
$$

Keterangan

$$
\begin{array}{ll}
\text { TLP } & \text { : titik layu permanen } \\
\text { KL } & \text { : kapasitas lapang } \\
\text { AT } & : \text { KL - TLP } \\
\mid \text { APWLI } & \text { : nilai absolut APWL } \\
\text { KAT } & \text { : kadar air tanah } \\
\text { TLP } & \text { : titik layu permanen } \\
\text { KL } & \text { : kapasitas lapang }
\end{array}
$$

Hasil dari ATS dibagi menjadi 5 kelas yang menyatakan ketersediaan air tanah seperti tertera pada Tabel 1.
Tabel 1. Persentase air tanah tersedia

\begin{tabular}{ll}
\hline $\begin{array}{l}\text { Air Tanah Tersedia } \\
\text { (ATS) }\end{array}$ & Persentase \\
\hline Sangat Kurang & $<10 \%$ \\
Kurang & $10-40 \%$ \\
Sedang & $40-60 \%$ \\
Cukup & $60-90 \%$ \\
Sangat Cukup & $90 \%$ \\
\hline
\end{tabular}

\subsection{Kesesuaian Lahan Tanaman Padi dan jagung}

Padi (bahasa latin: Oryza sativa L.) adalah salah satu tanaman budidaya terpenting dalam peradaban. Padi dapat tumbuh pada ketinggian 0-1500 mdpl.Tanaman padi dapat hidup baik didaerah yang berhawa panas dan banyak mengandung uap air. Curah hujan yang baik rata-rata $200 \mathrm{~mm}$ per bulan atau lebih, dengan distribusi selama 4 bulan, curah hujan yang dikehendaki per tahun sekitar 1500 - 2000 mm. Suhu udara yang baik untuk pertumbuhan tanaman padi berkisar antara $19-27^{\circ} \mathrm{C}$, namun suhu paling ideal adalah sekitar $23^{\circ} \mathrm{C}$.

Tabel 2. Spesifik kriteria klasifikasi oldeman (1975)

\begin{tabular}{cccc}
\hline No & Tipe & $\begin{array}{c}\sum \text { Bulan basah } \\
(\mathrm{CH}>200 \mathrm{~mm})\end{array}$ & $\begin{array}{c}\sum \text { Bulan } \\
\text { Kering } \\
(\mathrm{CH}<100 \\
\text { mm })\end{array}$ \\
\hline 1 & A1 & $>9$ bulan & $<2$ bulan \\
2 & A2 & $>9$ bulan & 2 bulan \\
3 & B1 & $7-9$ bulan & $>2$ bulan \\
4 & B2 & $7-9$ bulan & $2-3$ bulan \\
5 & B3 & $7-9$ bulan & $4-5$ bulan \\
6 & C1 & $5-6$ bulan & $<2$ bulan \\
7 & C2 & $5-6$ bulan & $2-3$ bulan \\
8 & C3 & $5-6$ bulan & $4-6$ bulan \\
9 & C4 & $5-6$ bulan & 7 bulan \\
10 & D1 & $3-4$ bulan & $<2$ bulan \\
11 & D2 & $3-4$ bulan & $2-3$ bulan \\
12 & D3 & $3-4$ bulan & $4-6$ bulan \\
13 & D4 & $3-4$ bulan & $7-9$ bulan \\
14 & E1 & $<3$ bulan & $<2$ bulan \\
15 & E2 & $<3$ bulan & $2-3$ bulan \\
16 & E3 & $<3$ bulan & $4-6$ bulan \\
17 & E4 & $<3$ bulan & $7-9$ bulan \\
18 & E5 & $<3$ bulan & $10-12$ bulan \\
\hline
\end{tabular}

Sedangkan jagung ( bahasa latin: Zea mays L.) merupakan tanaman semusim. Satu siklus hidupnya diselesaikan dalam 80-150 hari. Jagung biasanya cocok di lahan yang kering, kurang cocok di tanah yang terdapat air menggenang. Curah hujan ideal sekitar 85-200 mm/bulan dan harus merata (Rasyid dkk. 2010). Pada fase pembungaan dan pengisian biji perlu mendapatkan cukup air. Sebaiknya ditanam awal musim hujan atau menjelang musim kemarau. Membutuhkan sinar matahari, tanaman yang ternaungi, pertumbuhannya akan terhambat dan memberikan hasil biji yang tidak optimal. Kisaran suhu udara untuk syarat pertumbuhan tanaman jagung adalah antara $23^{\circ} \mathrm{C}-27^{\circ} \mathrm{C}$ dengan suhu optimal $25^{\circ} \mathrm{C}$. 
Selain itu, untuk mengetahui tingkat kesesuaian lahan tanaman padi dan jagung kita juga bisa menggunakan klasifikasi iklim Oldeman dan Frere. Oldeman dan Frere (1982) telah membuat klasifikasi iklim yang dihubungkan dengan pertanian menggunakan unsur iklim hujan. Kriteria yang dikemukakan oleh Oldeman didasarkan pada banyaknya Bulan Basah (BB) dan Bulan Kering (BK) seperti yang terlihat pada Tabel 2 .

Dari perhitungan yang dilakukan jumlah curah hujan $200 \mathrm{~mm} /$ bulan dipandang cukup untuk membudidayakan padi sawah. Untuk curah hujan sebesar $100 \mathrm{~mm} /$ bulan dipandang cukup untuk membudidayakan palawija. Oldeman (1975) dalam Tjasyono (2004) juga mendefinisikan bulan basah sebagai bulan dengan total curah hujan $>200 \mathrm{~mm} /$ bulan dan bulan kering sebagai bulan dengan < $100 \mathrm{~mm} /$ bulan, sedang bulan dengan curah hujan antara $100 \mathrm{~mm}-200 \mathrm{~mm}$ sebagai bulan lembab.

\section{Hasil dan Pembahasan}

\subsection{Analisis neraca air di Kota Bengkulu}

Dari data tersebut diketahui bahwa sejak tahun 1985 hingga tahun 2011 rata-rata jumlah curah hujan bulanan Kota Bengkulu berkisar antara 179-458 mm (lihat gambar 1). Peluang terjadinya hujan dengan intensitas lebat sangat dipengaruhi oleh faktor regional hingga lokal seperti efek Tropical Cyclone, Eddy, dan daerah Shearline di wilayah Bengkulu (Paski, 2014). Aliran massa udara yang berasal dari penguapan tinggi di Samudra Hindia yang bergerak menuju provinsi Bengkulu terangkat naik setelah terhalang oleh pegunungan Bukit Barisan sehingga pertumbuhan awan-awan konvektif sangat intensif. Wilayah Bengkulu umumnya memiliki tipe hujan equatorial dengan puncak hujan maksimum pada bulan Maret dan Desember. (Paski, 2015)

Rata-rata jumlah curah hujan terendah Kota Bengkulu terjadi pada bulan Agustus yaitu 179 mm, dan puncak tertinggi pada bulan Desember yaitu 458 mm. Terdapat 10 bulan basah $(\mathrm{CH} \geq 200 \mathrm{~mm})$ yakni bulan Januari hingga Juni dan September hingga Desember, dan 2 bulan lembab $(100 \mathrm{~mm}<\mathrm{CH}<200 \mathrm{~mm})$ yakni bulan Juli dan Agustus. Untuk evapotranspirasi di Kota Bengkulu berkisar antara 123,2 - 142,5 mm. Terendah yaitu 123,2 mm pada bulan Februari, tertinggi pada bulan Mei yaitu 142, $5 \mathrm{~mm}$. (lihat gambar 1)

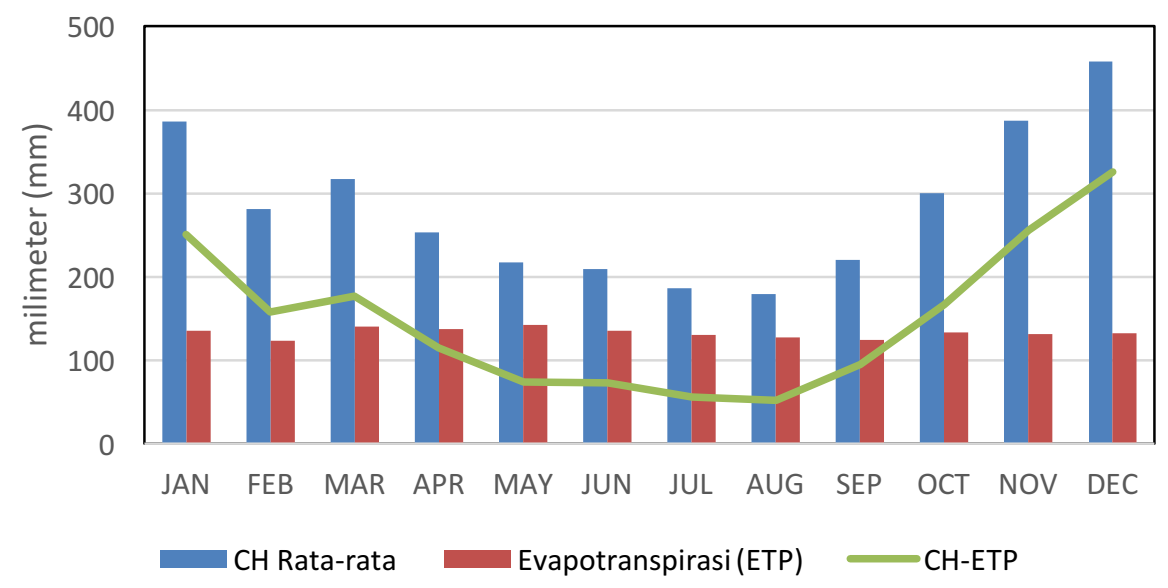

Gambar 1. Rata-rata curah hujan, evapotranspirasi lahan dan selisih curah hujan dan evapotranspirasi lahan bulanan tahun 1985-2011

Tabel 3. Hasil perhitungan neraca air

\begin{tabular}{ccccccc}
\hline Bulan & CH & ETP & CH-ETP & TLP & KL & AT \\
\hline JAN & 386 & 135.7 & 250.5 & 210 & 350 & 140 \\
FEB & 281 & 123.2 & 157.5 & 210 & 350 & 140 \\
MAR & 317 & 140.0 & 177.1 & 210 & 350 & 140 \\
APR & 253 & 137.2 & 115.3 & 210 & 350 & 140 \\
MEI & 217 & 142.5 & 74.2 & 210 & 350 & 140 \\
JUN & 209 & 135.1 & 73.5 & 210 & 350 & 140 \\
JUL & 186 & 130.4 & 55.6 & 210 & 350 & 140 \\
AGS & 179 & 127.5 & 51.8 & 210 & 350 & 140 \\
SEP & 220 & 124.9 & 94.7 & 210 & 350 & 140 \\
OKT & 300 & 133.0 & 166.5 & 210 & 350 & 140 \\
NOV & 387 & 131.3 & 255.8 & 210 & 350 & 140 \\
DES & 458 & 132.2 & 326.0 & 210 & 350 & 140 \\
\hline
\end{tabular}


Selisih curah hujan dan evapotranspirasi tertinggi pada bulan Desember yaitu $326 \mathrm{~mm}$, dan terendah pada bulan Agustus dengan jumlah 51,8 mm. Dari gambar 1 tersebut dapat dilihat bahwa tidak ada selisih antara curah hujan dan evapotranspirasi yang bernilai negative dalam arti lain tidak ada nilai evapotranspirasi lebih besar dari pada curah hujan bulanan selama periode 1985-2011. Oleh karena itu di kota Bengkulu potensial kehilangan air untuk penguapan (APWL) tidak terjadi. Jumlah air tersedia untuk Kota Bengkulu adalah sekitar $140 \mathrm{~mm}$. Didapat dari selisih antara kapasitas lapang dan titik layu permanen yang masing-masing adalah $350 \mathrm{~mm}$ dan 210 mm untuk Kota Bengkulu.
Kandungan air tanah di Kota Bengkulu sama dengan besar kapasitas lapangnya yakni $350 \mathrm{~mm}$ (lihat tabel 4). Hal ini dikarenakan curah hujan senantiasa lebih besar dibanding evapotranspirasi yang terjadi, sehingga potensial kehilangan air tidak terjadi. Dikarenakan kandungan air tanah pada setiap bulannya adalah sama, maka nilai dKAT $=0$. Karena jumlah curah hujan setiap bulannya lebih besar daripada jumlah evapotranspirasi potensialnya. Maka untuk evapotranspirasi aktualnya adalah sama dengan jumlah evapotranspirasi potensialnya. Dikarenakan nilai ETP = ETA, maka nilai defisit untuk Kota Bengkulu $=0$.

Tabel 4. Hasil perhitungan neraca air

\begin{tabular}{|c|c|c|c|c|c|c|c|}
\hline Bulan & KAT & dKAT & ETA & Defisit & Surplus & ATS & KAT \\
\hline JAN & 350 & 0 & 135.7 & 0 & 250.5 & 100 & Sangat Cukup \\
\hline FEB & 350 & 0 & 123.2 & 0 & 157.5 & 100 & Sangat Cukup \\
\hline MAR & 350 & 0 & 140.0 & 0 & 177.1 & 100 & Sangat Cukup \\
\hline APR & 350 & 0 & 137.2 & 0 & 115.3 & 100 & Sangat Cukup \\
\hline MEI & 350 & 0 & 142.5 & 0 & 74.2 & 100 & Sangat Cukup \\
\hline JUN & 350 & 0 & 135.1 & 0 & 73.5 & 100 & Sangat Cukup \\
\hline JUL & 350 & 0 & 130.4 & 0 & 55.6 & 100 & Sangat Cukup \\
\hline AGS & 350 & 0 & 127.5 & 0 & 51.8 & 100 & Sangat Cukup \\
\hline SEP & 350 & 0 & 124.9 & 0 & 94.7 & 100 & Sangat Cukup \\
\hline OKT & 350 & 0 & 133.0 & 0 & 166.5 & 100 & Sangat Cukup \\
\hline NOV & 350 & 0 & 131.3 & 0 & 255.8 & 100 & Sangat Cukup \\
\hline DES & 350 & 0 & 132.2 & 0 & 326.0 & 100 & Sangat Cukup \\
\hline
\end{tabular}

\subsection{Analisis kesesuaian lahan Tanaman Padi dan Jagung di Kota Bengkulu}

Pada kondisi rata-rata curah hujan bulanan setiap tahunnya berkisar antara 179-458 mm, suhu rata-rata bulanan Kota Bengkulu sejak tahun 1985 hingga 2011 berkisar antara $25,9-26,9^{\circ} \mathrm{C}$ (lihat Gambar 2). Suhu rata-rata terendah pada bulan Agustus dan tertinggi pada bulan Mei sesuai tipe iklim Oldeman A1, tanaman padi di Kota Bengkulu memiliki tingkat kesesuaian lahan tinggi, sedangkan jagung memiliki tingkat kesesuaian rendah meskipun dari suhu ratarata bulanannya tanaman jagung memiliki tingkat kesesuaian sedang.

Tabel 5. Evapotranspirasi lahan dan tanaman padi dan jagung

\begin{tabular}{lccc}
\hline \multicolumn{1}{c}{ Bulan } & ETP lahan & ETC padi & ETC jagung \\
\hline Jan & 135.7 & 153.3 & 107.2 \\
Feb & 123.2 & 139.2 & 97.3 \\
Mar & 140.0 & 158.2 & 110.6 \\
Apr & 137.2 & 155.1 & 108.4 \\
May & 142.5 & 161.0 & 112.5 \\
Jun & 135.1 & 152.7 & 106.7 \\
Jul & 130.4 & 147.4 & 103.0 \\
Aug & 127.5 & 144.1 & 100.7 \\
Sep & 124.9 & 141.1 & 98.7 \\
Oct & 133.0 & 150.3 & 105.1 \\
Nov & 131.3 & 148.4 & 103.7 \\
Dec & 132.2 & 149.3 & 104.4 \\
\hline
\end{tabular}

Untuk evapotranspirasi pada tanaman, dipengaruhi oleh koefisien tanaman pada masingmasing jenis. Evapotranspirasi padi $=1,13 \mathrm{x}$ evapotranspirasi lahan, sedangkan Evapotranspirasi jagung $=0,79 \mathrm{x}$ evapotranspirasi lahan

Evapotranspirasi tanaman padi dan jagung dengan jumlah maksimum dan minimum terjadi pada bulan yang sama dengan evapotranspirasi lahan, yaitu maksimum terjadi pada bulan Mei, ETC padi $=161,0 \mathrm{~mm}$, dan ETC jagung $=112,5 \mathrm{~mm}$. Sedangkan jumlah minimum pada bulan Februari yaitu padi $=139,2 \mathrm{~mm}$ dan jagung $=97,3 \mathrm{~mm}$. (Lihat Tabel 5)

Dari gambar 3 dapat dilihat bahwa surplus air tanah tanaman jagung lebih tinggi daripada surplus tanaman padi. Surplus air tanah tanaman padi mempunyai pola yang sama dengan surplus lahan. Surplus maksimum terjadi pada bulan Desember dengan jumlah 308,8 mm. Dan jumlah minimum 35,2 mm terjadi pada bulan Agustus. Begitu pula surplus air tanah tanaman Jagung, jumlah maksimum terjadi pada bulan Desember dan minimum pada bulan Agustus, masing-masing 353,8 $\mathrm{mm}$ dan 78,6 mm. Hal ini dikarenakan tanaman jagung membutuhkan lebih sedikit air daripada tanaman padi.

Dari syarat tumbuh tanaman, tingkat kesesuaian lahan pada kondisi curah hujan tinggi seperti di Kota 
Bengkulu ini, untuk penanaman tanaman padi memiliki tingkat kesesuaian tinggi sedangkan tanaman jagung memilki tingkat kesesuaian rendah. Meskipun pada kondisi suhu yang ada, tanaman padi tetap memiliki tingkat kesesuaian tinggi, sedangkan jagung memiliki tingkat kesesuaian sedang. Karena tanaman jagung biasanya sesuai ditanam pada lahan yang kering, bukan pada lahan yang terdapat air yang menggenang.

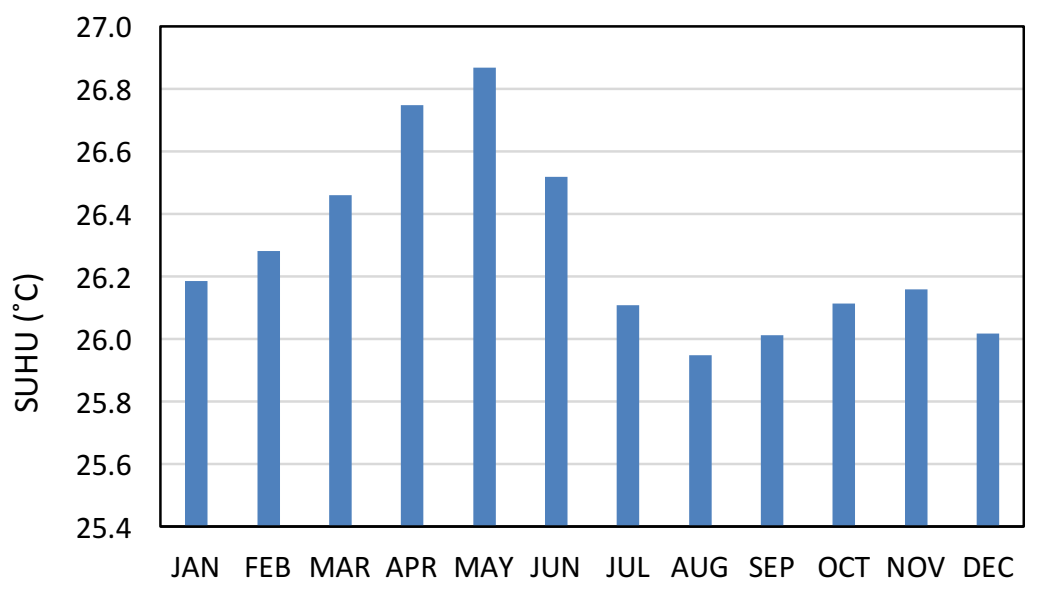

Gambar 2. Rata-rata Suhu Udara Bulanan Tahun 1985-2011

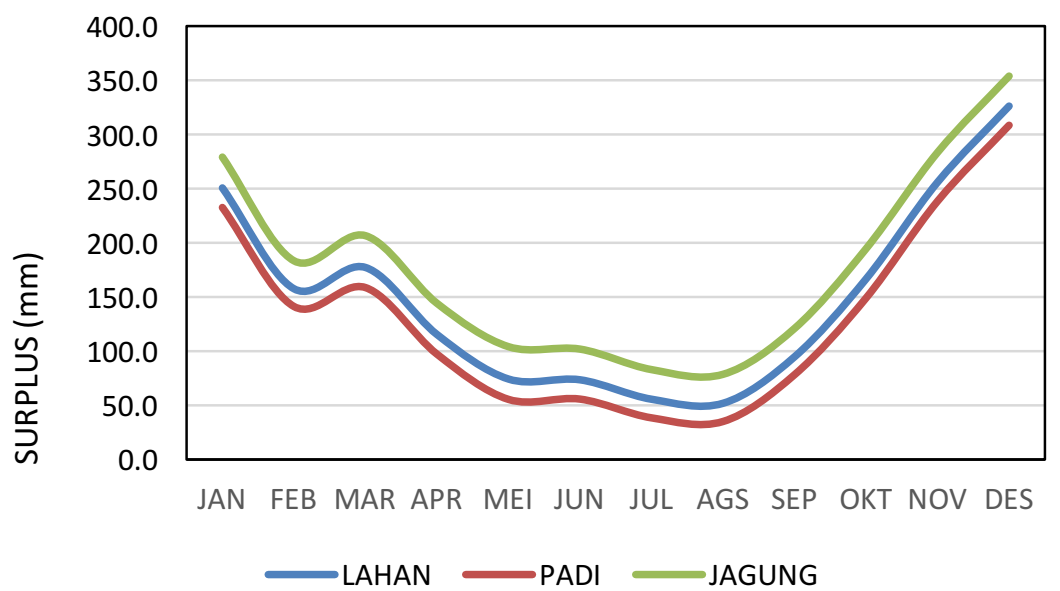

Gambar 3. Rata-rata Surplus Ketersediaan Air Bulanan Tahun 1985-2011

\section{Kesimpulan}

Berdasarkan hasil analisis, wilayah Kota Bengkulu memiliki persentase ketersediaan air ratarata bulanan sebesar 100\%. Dengan demikian Kota Bengkulu memiliki potensi nilai surplus ketersediaan air tanah sepanjang tahun. Pada kondisi rata-rata jumlah curah hujan bulanan yang cukup tinggi berkisar antara 179 - $458 \mathrm{~mm}$, rata-rata suhu yang relatif rendah berkisar $25,9-26,9{ }^{\circ} \mathrm{C}$, dan lahan dengan nilai surplus yang tinggi seperti ini, di wilayah Kota Bengkulu sesuai untuk ditanami padi, sedangkan untuk penanaman jagung kurang sesuai.

Dengan melihat jumlah curah hujan yang ideal untuk syarat tumbuh tanaman, Kota Bengkulu dapat ditanami padi sepanjang tahun dengan jadwal tanam pertama bulan November - Februari, jadwal tanam kedua bulan Maret - Juni, dan jadwal tanam ketiga bulan Juli - Oktober. Pada kondisi ketersediaan air tanah seperti di Kota Bengkulu ini, kurang sesuai untuk dilakukan penanaman tanaman jagung, ada baiknya untuk mencoba tanaman palawija lain.

\section{DAFTAR PUSTAKA}

Bari, M.A, and K. R. J. Smettem. 2006. A conceptual model of daily water balance following partial clearing from forest to pasture. Hydrol. Earth Syst. Sci. 10: 321-337 Binh, N.D., V.V.N.

Chang, J. H. 1968. Climate and Agriculture. An Ecology Survey. Chicago : Aldine Publ. Co

Frère, M \& Popov, G. F. 1979. Agrometeorological crop monitoring and forecasting, Food and Agriculture Organization of the United Nations, Rome 
Hillel, D. 1972. "The field water balanced and water use efficiency," in: Optimizing the Soil Physical Environment Toward Greater Crop Yields. Academic Press, New York, pp 79-100

Kumambala, P.G and Ervine, A. 2010. Water Balance Model of Lake Malawi and Its Sensitivity to Climate Change. The Open Hydrology Journal4: 152-162

Lascano, R.J. 2000. A General System to Measure and Calculate Daily Crop Water Use.J. Agron 92: 821-832.

Latha, J. , Saravanan and Palanichamy. 2010. A Semi Distributed Water Balance Model for Amaravathi River Basin using Remote Sensing and GIS. International Journal of Geomatics and Geosciences 1:252-263.

Nasir A.N, dan S. Effendy. 1999. KonsepNeraca Air Untuk Penentuan PolaTanam. Kapita SelektaAgroklimatologi Jurusan Geofisikadan Meteorologi FakultasMatematika dan IPA. Institut Pertanian Bogor.

Oldeman, L.R. 1975. An Agroclimatic Map of Java. Contribution from The Central Research Institute for Agriculture no. 17. CRIA. Bogor.Sosiawan, H., et al. 2006. Penyusunan Zona Agroekologi (ZAE) Kabupaten Merauke Provinsi Papua. Laporan Hasil Penelitian BPTP Papua TA 2006. Balai Pengkajian Teknologi Pertanian Papua. Tidak dipublikasi. 87 hal.

Oldeman L.R. dan M. Frere,. 1982. A Study of the Agroclimatology of the Humid Tropics of South-east Asia. WMO Interagency Project on Agroclimatology.

Paski, J. A. I. 2014. Analisis Kejadian Cuaca Ekstrim Tanggal 20 April 2014 di Kota Bengkulu Memanfaatkan Citra Radar dan Satelit. Buletin Balwil II BMKG. Vol: 4 No 9

Paski, J. A. I dan Anjasman. 2015. Penggolongan Sel Awan Konvektif Penyebab Angin Kencang di Pesisir Barat Bengkulu Berdasarkan Gema Citra Radar (Studi Kasus 22 Februari 2014). Sekolah Tinggi Meteorologi Klimatologi dan Geofisika (STMKG Jakarta).

Rafi, Z., and Ahmad, R. 2005. Wheat Crop Model Based on Water Balance for Agrometeorological Crop Monitoring. Pakistan Journal of Meteorology 2:23-33

Rasyid, B., Samosir, S.S.R., dkk. 2010. Respon Tanaman Jagung ( Zea Mays ) pada BerbagaiRegim Air Tanah dan Pemberian Pupuk Nitrogen. Prosiding Pekan SereliaNasional Tahun2010. Jurusan Ilmu Tanah Fakultas Pertanian UniversitasHasanudin, Makasar.

Soepangkat. 1992. Pengantar Pengamatan Permukaan Meteorologi Jilid 1. Balai Diklat Meteorologi dan Geofisika : Jakarta.

Sosrodarsono, S. dan Takeda, K. 1978. Hidrologi untuk Pengairan. Jakarta: PT. Pradnya Paramita.

Thornthwaite, C.W., and J.R. Mather. 1957. Instructions and tables for computing potential evapotranspiration and the waterbalance: Centeron, N.J., Laboratory of Climatology, Publication in Climatology, Vol. 10, no. 3, pp. 185-311.

Tjasyono, B. 2004. Klimatologi. Ed. Ke-2. Penerbit ITB, Bandung.

Veihmeyer, F.J. and Hendrickson, A.H. 1955. Does transpiration decrease as the soil moisture decreases?. Transactions, American Geophysical Union 36: doi: 10.1029/TR036i003p00425. issn: 0002-8606. 